The Impact of Economic Deprivation and Regional Differences on Individual Secularization in Western Europe

\author{
Gundelach, Peter
}

Published in:

Nordic Journal of Religion and Society

Publication date:

2014

Document version

Publisher's PDF, also known as Version of record

Document license:

Unspecified

Citation for published version (APA):

Gundelach, P. (2014). The Impact of Economic Deprivation and Regional Differences on Individual Secularization in Western Europe. Nordic Journal of Religion and Society, 27(2), 131-150. 


\section{THE IMPACT OF ECONOMIC DEPRIVATION AND REGIONAL DIFFERENCES ON INDIVIDUAL SECULARIZATION IN WESTERN EUROPE}

\section{Abstract}

This article studies secularization at the individual level in a «most similar approach» study of 13 Western European countries. Secularization is measured in two ways: as a decrease in Christian beliefs and as a decrease in the correlation between Christian beliefs and morality. In particular, the article scrutinizes the impact of two factors that are traditionally considered important for secularization: cohort and country. Based on data from the European Values Study, the article shows that the impact of cohort is primarily related to the individual's economic deprivation during his/her formative years. A sub-country regional analysis compares the impact of the country and denomination as social institutions and finds "within country» differences important in secularization and, in many cases, the impact of denomination as a social institution is identical in regions in different countries.

Keywords: secularization, Europe, cohort, social institutions, values

\section{Introduction}

Until the last decades of the $20^{\text {th }}$ century, the process of secularization was almost considered a social fact - a permanent and irreversible process. However, evidence has gradually shown that religious change takes different paths in different parts of the world and that secularization in Western Europe is an exception compared to religious change in other parts of the world (see Davie 2000; Joas and Wiegandt 2009). For instance, Americans are very religious, and Putnam and Campbell (2012) argue that American society is becoming increasingly polarized religiously. There is a religious revival in several countries in Eastern and Central Europa (Tomka 2011), and religious development has taken a different path in many Third World countries. This research 
does not mean that the theory of secularization must be abandoned but that the scope of the theory must be made clearer. With respect to secularization, Western Europe is the exceptional case (Davie 2002). Hence, the «most different» comparative studies approach - in which generalizations are made based on a large number of different countries-must be supplemented with «most similar» studies, which make it possible to scrutinize secularization in more detail by selecting relatively similar countries or by comparing clusters of countries from different regions in the world (see Stark 2001). This article limits the analysis of secularization to Western Europe, where research has found a consistent, gradual decline in church attendance (Davie 2000, 2002). The article analyses a selection of Western European countries that are relatively similar, where «the prevailing conception of God is the conventional Christian deity» (Stark 2001: 625). The selection of such countries makes it possible to go into detail with the two core variables that are traditionally used to explain secularization: cohort changes and country characteristics.

The article contributes to the literature in three ways. First, it gives a nuanced analysis of the process of secularization by studying it both as a belief system and as a relational concept - i.e., secularization is analyzed both as a change in the development of Christian beliefs and as change in the relationship between Christian beliefs and morality. Second, it offers an interpretation of the relationship between cohort and secularization. Third, this article will compare sub-country regions with the purpose of studying how secularization may be explained by country-based or border-crossing social institutions.

After discussing the measurement of individual-level secularization, the article proceeds in two steps: first, a descriptive analysis of secularization in selected countries in Western Europe and, second, detailed discussion of individual-based and countrybased explanations of secularization.

\section{Measuring Secularization}

Secularization may be understood as a process that takes place at different levels (societal, organizational and individual levels, see Dobbelare 2002). Based on survey data, this article limits its analysis to secularization at the individual level. Three different types of measures for secularization have been suggested: church attendance, religious values and the relationship between religious and secular values.

Many studies have investigated secularization by studying church attendance, which is a relatively easy and, perhaps, «objective» way of measuring integration in the church. As argued by Lüchau (2014a), the problem is that church attendance can be measured both as a measure of orthodoxy and personal religiosity. For instance, a recent Danish study demonstrated a small increase in church attendance — especially at Christmas time. This, of course, may be due to increased religious motivations, but another possibility is that church attendance at Christmas may be an attempt to reinvent family traditions in a society with few traditions (Andersen and Lüchau 2011; Lüchau 2014a). 
There is a lack of reliable data about developments in church attendance over very long time spans; and, to my knowledge, there are no systematic studies of church attendance prior to WWII. In the period after the war, a study from West Germany (Meulemann 1983) and unpublished data from Lüchau (2014b) show strikingly similar results: a steep decrease in church attendance from 1950 to about 1970 and a much smaller decline after 1970.

A second type of operationalization focuses on social values - for instance, the belief in Christian dogmas (Andersen et al. 2013; Halman and Draulans 2006). Theoretically, the advantage of this operationalization is that the interpretation is less fuzzy than church attendance and that it is possible to address core Christian beliefs rather than just referring to God in more general terms as has been done in several studies. The disadvantage is that Christian dogmas may be perceived by some respondents as old-fashioned or difficult to relate to.

The third operationalization is based on the degree of the relationship between religious and secular values. This operationalization has been advanced, among others, by Wilson (1982) and Bruce (2011). The idea is that religious values become less authoritative in relation to other social values-i.e., there is increased value segmentation. Of special interest here is the relationship between moral and religious values, but the empirical relationship between religiosity and morality seems to depend on the type of morality that is studied. "Sexual morality» and "morality sanctioned by the state» (Finke and Adamczyk 2008) seem to be differently related to religiosity. There is evidence of relatively high correlations between religious beliefs and practices and sexual morality but lower correlations with state-sanctioned morality (Finke and Adamczyk 2008; Parboteeah et al. 2008). Second, the correlations differ according to the kind of religious values that are studied. In general, it seems that moral beliefs are more consistently and strongly related to values that emphasize the importance of religion or religious beliefs than to behavioral measures such as church attendance (Desmond and Kraus 2014; Finke and Adamczyk 2008).

Since there is evidence that religious values seem to have greater impact on morality than church attendance (Finke and Adamczyk 2008), I have chosen to use religious beliefs as a core variable in measuring secularization. This variable is supplemented with the value fragmentation variable, i.e. that secularization is measured as the lack of correlation between religious and secular values.

As mentioned above, the first part of the article is a descriptive analysis of the development in secularization. Consistent with most of the literature (Davie 2000; Halman and Draulans 2006), the first hypothesis states that there is a small increase in secularization in Western Europe in recent decades. This means that:

H1: the level of religious beliefs and the correlation between religious beliefs and secular values have become lower in recent decades.

This hypothesis is tested in a long-term perspective among countries that have participated in the European Values Survey during the period 1981-2008. Having established the expected tendency toward secularization in these countries, the article goes on to 
analyze macro- and micro-explanations for secularization. At the macro-level, studies of countries play a major role, but the article argues that this analysis must be supplemented with a study of social institutions. At the individual level, the cohort is the most common variable, and the article argues that cohort is a «container» variable and tests three ways to interpret this variable.

\section{Country-Based Explanations}

Most of the comparative research on secularization have been governed by a soft version of modernization theory. This theory has two elements: an evolutionary and a structural-functional perspective. The evolutionary perspective dates from Auguste Comte (1798-1857), who argued that countries develop from less to more advanced societies and, consequently, that countries may be ranked in an unilinear way according to some degree of modernization. In contemporary studies, this has been interpreted to mean a development towards societies characterized by more individualistic, libertarian, and rational values. The structural-functional theory argues that a fragmented value structure creates problems for social integration. In relation to secularization, value fragmentation means that the importance of religious values for secular values is diminishing. Modernization is often assessed by wealth (measured by GDP, gross domestic product, or, PPP, purchasing power parity) or some measure of the level of technological innovations. Such factors lead to individualization, which comprises changes in all parts of society including the fact that traditional and institutionalized forms of religiosity will decrease (see Inglehart 1997; Inglehart and Wenzel 2005).

Modernization theory is not by definition a study of nations. It would be equally possible to study clusters of countries (see Voas and Doebler 2014) or sub-national regions, but the analytic and empirical consequences of the modernization approach have generally been to compare countries that vary according to some of the core components of modernization theory. One reason for this approach is probably that the statistical data sources are much better for country variables than for other geographical units.

A more advanced strategy is to combine country and individual variables, using multi-level analyses. Ruiter and van Tubergen (2009), for instance, distinguished between individual explanations for religiosity and two types of country explanations: compositional (explained by individual characteristics of the population in the countries) or contextual (explained by specific country characteristics). Among the country variables in Ruiter and Tubergen's study are the degree of religious regulation, tertiary school enrolment, economic inequality (Gini coefficient), experience of war and urbanization. A similar study with very similar variables and results has been conducted by Moor (2014).

One of the problems with this kind of analysis is that countries tend to come in «packages». The Scandinavian countries, for instance, are all wealthy with high levels of education and low inequality. Splitting up countries in a number of independent variables does not account for the historically-established interdependency of the various 
elements. One way of approaching this issue is to focus on the impact of social institutions on religiosity.

\section{Social Institutions}

Empirical analyses based, for instance, on European Values Study (EVS) data revealed that modernization theory did not satisfactorily explain the dynamics of value change in Europe (Arts and Halman 2014: 3). As an alternative, a social institutional approach has been suggested (Gundelach 1994; Haller 2002). Countries are not just geographical entities but also state institutions with a legal regulatory system that governs policy areas including policies related to the church. However, state institutions are not the only institutions that influence values. Some institutions are not limited to a single country but are characteristic of several countries. Institutions may also vary in different parts of a country such as, for instance, traditional religious organization or traditional family structures (Todd 1985). In order to grasp border-crossing or sub-country institutions, we need to supplement the country as a unit of analysis with a study of subcountry structures.

In this article, I have chosen to do a relatively simple analysis of the impact of institutions. I compare the distribution of religious values between regions whether they belong to the same country or not. Country-based explanations cannot be ruled out but will be supplemented with analyses of border-crossing institutions. These deliberations lead to two supplementary hypotheses:

The difference between Christian beliefs and value fragmentation follows (H2a) state boundaries (the state matters) or ( $\mathrm{H} 2 \mathrm{~b})$ boundary-crossing institutions (institutions matter).

A related way of criticizing the focus on countries is Ulrich Beck's argument about global processes. Beck uses the term «methodological nationalism» to criticize the focus on countries rather than global processes. According to Beck, globalization implies that normal social science categories are becoming zombie categories, i.e., «living-dead» categories that «blind the social sciences to the rapidly changing realities inside the nation-state containers» (Beck 2002: 24). Rather than studying countries as a unit, according to Beck, we should study global phenomena that cross borders. One example might be the increased insecurity that is a condition for young generations all over the world (Beck \& Beck-Gernsheim 2009). This line of thinking changes the focus from country-based analyses to individual-based explanations related to generations or to use a more general concept: cohorts.

\section{Individual Explanations: Cohorts}

Individual-based explanations of secularization often focus on cohorts (Davie 2000). The basic idea in a cohort explanation is that the experiences in people's formative 
years influence their values and behavior later in life. «Each new cohort makes fresh contact with the contemporary social heritage and carries the impress of the encounter through life» (Ryder 1965: 844). In values studies, this theory is most prominently advanced by Inglehart (1997). In relation to social change, the implication of the cohort theory is that different cohorts tend to have identical values because they are influenced by identical societal conditions. Even though the values of a cohort tend to be stable during its lifetime, change occurs because new cohorts are influenced by new social conditions and, hence, acquire new values.

Just like country, cohort is a «container» variable that needs to be filled with specific information. In this article, I distinguish between three types of cohort-based characteristics: existential insecurity, education and religious socialization.

1. Existential insecurity. Inglehart (1997) and Norris and Inglehart (2004) have stressed the impact of living conditions, during individuals' formative years, on religion. They argue that people who have grown up in a situation characterized by relatively insecure conditions tend to focus more on religion than people who have grown up in relative security. Existential security is the «feeling that survival is secure enough that it can be taken for granted» (Inglehart and Norris 2004: 2). Existential insecurity may have many components. An example of a broad analysis is the study of 26 countries by Immerzeel and van Tubergen (2013) in which they analyze a large number of insecurities such as becoming unemployed, losing a partner or experiencing war. Immerzeel and van Tubergen found that all kinds of insecurities were important in explaining religiosity. However, lumping different insecurities such as the experience of war or unemployment in the same concept seems theoretically less fruitful. Instead, I will focus on financial uncertainties, which seem to be the focus of Norris and Inglehart's theory (2004). This variable will be called economic deprivation in the following analysis.

2. Formal education is also an important factor for secularization. Stubager (2008) identifies three general effects of school socialization: psychodynamic factors (control over own life), cognitive factors (sophisticated reasoning), and socialization (internalization of values). In schools, education is becoming more rationalist and tends to provide «information about rather than in religious beliefs» (Davie 2000); and, according to Moor (2014), highly-educated people have less need for religion because, in general, they have higher cognitive capacities. However, this conclusion does not apply to all survey research (Norris and Inglehart 2004), and there seems to be a complex relationship between education and religion at both the country and individual level.

3. Religious socialization. The impact of generational socialization is strongly stressed by Voas and Doebler (2014), who convincingly show that decline in church attendance is primarily due to the lack of the generational transfer of values. Children of non-churchgoers in Britain rarely engage in church attendance (Voas and Crockett 2005). Voas and Doebler's multilevel models of EVS data show that people who are regular churchgoers are more likely to see the transmission of faith as important, and they conclude that «ultimately religion depends on the commitment of one generation to pass it on to the next» (Voas and Doebler 2014: 248). 
There may be different agents of religious socialization: parents, peers, or the school (see Cornwall 1988). Himmelfarb (1980) has argued that socialization in these groups may be mutually reinforcing since parents may socialize their children in religion by channeling them into other groups or organizations that will reinforce what was learned at home. Channeling presupposes that socialization begins in the family, but it is, of course, possible that secondary socialization in school or confirmation classes have an equally strong or, perhaps, even stronger impact on the individual's religiosity than family socialization. For instance, Davie (2002) has argued that, in spite of major differences in the relationship between schools and religion in different parts of Europe, there is a general tendency for school education to become more secular.

The three types of explanation may be considered supplementary. Hence, the following hypotheses may be formulated:

Secularization is stronger among individuals who $(\mathrm{H} 3 \mathrm{a})$ have a high education, (H3b) have a low degree of religious socialization and $(\mathrm{H} 3 \mathrm{c})$ experienced a low degree of economic deprivation during their formative years.

\section{Data, Analytical Strategy and Measurement}

\section{Data}

This article is based on data from the European Values Study, which was carried out in European countries in four waves: 1981, 1990, 1999 and 2008. Identical questionnaires were used in the different countries in each year, and there were large overlaps between the questions in each wave. ${ }^{1}$

In order to analyze long-term changes, this article has selected only countries that participated in the EVS project in all four waves: Belgium, Denmark, France, West Germany, Iceland, Ireland, Italy, Malta, the Netherlands, Spain, Sweden, Great Britain, and Northern Ireland. The total number of respondents is 64,792 .

Unfortunately, some of the most theoretically relevant variables are not included in the combined dataset 1981-2008 but only in the 2008 data. Thus, the second part of the article, which includes analyses of regions, is only based on 2008 data. This part of the article only includes countries with a regional structure, i.e. more than two regional units.

\section{Analytical Strategy}

The analytical strategy in the article is to focus on relationships rather than only on the dependent variable (Aneshensel 2002). For this reason, traditional regression analysis is less suited to the analysis. Instead, graphical chain models (Lauritzen 1996) using the DIGRAM software (Kreiner 1996, 2013) were applied. The software allows for the analysis of ordinal data with one of several variables at the same level in the causal structure and provides the possibility of testing the collapsibility of regions. The procedure is based on the principle of table analysis for which there is a long tradition in 
the social sciences (Aneshensel 2002; Davis 1971; Lazarsfeld and Rosenberg 1955). The idea is to analyze all relationships between variables when controlled for the other variables in the model. Partial $\gamma$-coefficients are used to measure associations. ${ }^{2}$

The statistical collapsibility procedure means that regions are collapsed if the distribution of Christian beliefs in one region does not significantly differ from the distribution of Christian beliefs in another region, given the other variables in the model. After two regions have been collapsed, they are considered to be one new category, which is compared with the other categories, and the analysis continues until there are significant differences between all categories of regions.

\section{Measurement}

The analysis includes the following variables: Secularization, which is measured in two ways: 1) as a change in Christian beliefs and, 2) as a change in the relationship between Christian beliefs and morality. The intervening variables are education, religious socialization and economic deprivation and the independent variables are cohort, country, and region.

\section{The dependent variables:}

The variable Christian beliefs is an index that is based on four items: "Which, if any, of the following do you believe in? God, Hell, Heaven, Sin». Respondents were asked to answer 'yes' or 'no' to each question. These items form an index in which Loevinger's $\mathrm{H}=0.845$ and Chronbach's Alpha $=0.826$. The index was constructed by computing the number of 'yes' answers. This index has previously been used by Andersen et al. (2013).

Morality is defined as behaviors «which were and often still are regarded as sinful according to traditional Christian doctrine» (Halman and van Ingen 2013). The EVS questionnaire asks people whether a certain kind of behavior can be justified on a 10point scale from $1=$ can never be justified to $10=$ can always be justified. Four items have been selected: Justification for divorce, euthanasia, suicide, taking soft drugs. Based on these items, an additive index was constructed (Loevinger's $\mathrm{H}=0.470$, Cronbach's alpha $=0.710$ ). In the analysis, the index was recoded into four categories.

The intervening variables:

Education: «What is the highest level of education you have completed in your education?» (recoded into three categories).

Socialization: «Apart from weddings, funerals and christenings, about how often did you attend religious services when you were 12 years old?» (eight response categories).

Economic deprivation: «When you think about your parents, when you were about 14 years old, could you say whether this statement correctly describes your parents? My parent(s) had problems making ends meet» (four response categories). 
The independent variables:

Country: Respondent's country of residence.

Cohort is measured by year of birth and coded in the following categories: 1 (1918) 2 (1919-1927) $3(1928-1936) 4(1937-1945) 5(1946-1954) 6(1955-1963) 7$ (1964-1972) 8 (1973-1981) 9 (1981-).

Regions: The regional analysis is based on the EU's Nomenclature of Territorial Units for Statistics (NUTS). For the analysis, the NUTS2 level has been used. NUTS2 represents what most countries call «regions», which is the middle administrative level between country and local districts. Among the relevant countries, several had to be omitted. The respondents' NUTS2 location was not registered in Norway. Iceland, Malta, and Northern Ireland have only one region. Ireland only has two regions. These countries were omitted from the analysis. Former East Germany is included in the dataset. This means that a total of nine countries (or 10 if East and West Germany are seen as two different units) are part of the data set: Belgium, Denmark, France, Italy, Netherlands, Spain, Sweden, Great Britain, East and West Germany. The NUTS2 classification is applied in different ways in different countries. In Germany, for instance, the NUTS2 classification includes 37 categories and, in Great Britain, 36 categories. In other countries, the NUTS 2 classification has many fewer units. Due to the low number of interviews in some regions, an initial discretionary reduction of the 130 NUTS2 regions was carried out. The number of regions was reduced to 13 in Germany and 12 in Great Britain, and similar reductions were carried out in other countries. This procedure resulted in recoding the total number of NUTS2 categories into 50 regions.

\section{Results}

This section begins with a descriptive analysis of secularization in the 13 countries in which the EVS study was carried out four times from 1981 to 2008 and moves on to analyze secularization in cohorts and regions based on 2008 data.

\section{Secularization from 1981 to 2008}

As a background for the subsequent causal analysis, the first task is to show that the general process of secularization in Europe (Davie 2000; Norris and Inglehart 2004) is occurring in the countries that have been selected for the analysis. As mentioned above, secularization is measure in two ways: as decrease in Christian beliefs and as decrease in the correlation between Christian beliefs and morality. The results are shown in Table 1. 
Table 1. Christian beliefs (means) and $\gamma$-correlations between Christian beliefs and morality (1981-2008).

\begin{tabular}{|l|c|c|c|c|}
\hline & \multicolumn{2}{|c|}{ Christian beliefs } & $\begin{array}{c}\text { Correlation between morality } \\
\text { and Christian beliefs }\end{array}$ \\
\hline & $\mathbf{1 9 8 1}$ & $\mathbf{2 0 0 8}$ & $\mathbf{1 9 8 1}$ & $\mathbf{2 0 0 8}$ \\
\hline Denmark & 1.12 & 1.05 & 0.46 & 0.31 \\
\hline Sweden & 1.23 & 0.75 & 0.37 & 0.47 \\
\hline France & 1.45 & 1.37 & 0.38 & 0.27 \\
\hline Netherlands & 1.68 & 1.43 & 0.44 & 0.52 \\
\hline Belgium & 1.71 & 1.55 & 0.24 & 0.31 \\
\hline West Germany & 1.76 & 1.69 & 0.44 & 0.27 \\
\hline Iceland & 2.06 & 1.78 & 0.32 & 0.28 \\
\hline Italy & 2.19 & 2.22 & 0.48 & 0.43 \\
\hline Great Britain & 2.26 & 1.90 & 0.28 & 0.36 \\
\hline Spain & 2.28 & 1.85 & 0.47 & 0.47 \\
\hline Ireland & 3.17 & 2.62 & 0.46 & 0.33 \\
\hline Malta & 3.53 & 3.51 & 0.57 & 0.53 \\
\hline
\end{tabular}

The countries in Table 1 are sorted according the mean of the Christian beliefs variable in 1981. The table shows considerable variation in the support for Christian beliefs with Denmark and Sweden at the one extreme with low support for Christian beliefs and Ireland and Malta at the other extreme with high support. There is a decrease in Christian beliefs in 12 of 13 countries and stagnation in Italy. Hence, this part of the table generally supports hypothesis 1 . The results for the correlations are more complex. In most countries, there is the hypothesized decrease in correlations between Christian beliefs and morality; but, in Sweden, the Netherlands, Belgium, and Great Britain, there is an increase. These countries are quite different, and there does not seem to be an evident explanation for the different developments in the countries with respect to the correlation between morality and Christian beliefs.

In spite of this variation, it seems acceptable to say that there is a general tendency towards secularization in 13 countries in Western Europe and that hypothesis 1 is corroborated. The next step is to understand this development in two ways: at the individual level and at the country and regional level.

\section{Cohort and Secularization}

Cohorts are people born at a specific point in time, and the impact of cohorts on religion (or any other variable for that matter) begs the question of what exactly it is about cohorts that has an impact on secularization. Statistically, this means treating the different char- 
acteristics related to cohorts as intervening variables between cohort and the two measures of secularization. Hypothesis 3 listed three intervening variables that all are related to the individual's formative years: economic deprivation, religious socialization and education. When these variables are simultaneously included as intervening variables between cohort and Christian beliefs, a very clear picture emerges. Christian beliefs have no correlation with economic deprivation, a very small correlation with education ( $\gamma=$ $0.05)$ and a very strong correlation with religious socialization $(\gamma=0.38)$. In other words, there is strong support for hypothesis $3 \mathrm{~b}$ (about religious socialization), whereas hypothesis $3 a$ (education) and $3 c$ (material deprivation) are refuted. Thus, the impact of cohort on secularization is best understood by the impact of religious socialization.

Younger cohorts have not been as socialized into religion. Hence, the consequence of the strong relationship between socialization and Christian values may be interpreted as a very strong mechanism in the transfer of religiosity. In general, older cohorts have received more religious socialization than the younger cohorts. Hence, there is a stronger transmission of religiosity in older than in younger cohorts. Since values tend to be stable, value change will influence society as the cohorts become older. That is, when people who are not as socialized into religion have children, these children will be even less socialized into religion. This process results in a decline in Christian beliefs in society.

The decrease in religious socialization does not only create a decline in Christian beliefs, it also produces increased value fragmentation between Christian beliefs and morality. The $\gamma$ correlation is 0.38 for people born before 1946 and 0.28 for people born in 1946 or after. This means that value fragmentation will increase as younger cohort replace older cohorts. In sum, the decrease in religious socialization will result in a decline in Christian beliefs and a decline in the impact of Christian beliefs on socialization.

\section{Country, Region and Religiosity}

Both religion and country are institutions that confer identity and values to the individual (Martin 1978), and these institutions interact in relation to shaping religious values. Some of the social institutions (e.g. state regulations) vary in different countries while others (e.g. religious institutions) are relatively similar in different countries. If countries are divided into regions, it is possible to estimate whether there is greater similarity between regions within a country or between regions in different countries. In relation to secularization, this means studying whether it is a country-based institution (state regulation) or a border-crossing institution (in this case, the religious denomination that has traditionally dominated a region) that explains secularization.

The means of Christian beliefs and the correlation between Christian beliefs and morality is depicted in Table 2 . The rows in the table are sorted in such a way that the regions with the highest mean of Christian beliefs are in the top row of the table and the lowest mean in the bottom row. The statistical analysis (not detailed here) shows that the distribution of the variable «Christian beliefs» is identical for each group in the region, given the other variables in the statistical model. Based on the collapsibility method mentioned above, the 50 regions have been reduced to 11 categories. $^{3}$ 
The table may be read in two ways: horizontally and vertically. The rows represent the collapsed regions, and the columns display the values of the dependent variables for each regional category.

Table 2. Means of Christian beliefs and the correlation between Christian beliefs and morality in collapsed regions in Europe.

\begin{tabular}{|c|c|c|c|c|}
\hline Collapsed regions & $\begin{array}{l}\text { Christian } \\
\text { beliefs: } \\
\text { Means }\end{array}$ & $\begin{array}{l}\text { Partial } \gamma- \\
\text { correlation } \\
\text { between } \\
\text { beliefs and } \\
\text { morality }\end{array}$ & $\begin{array}{l}\text { Pet. who say } \\
\text { they belong } \\
\text { to a } \\
\text { Catholic } \\
\text { denominati } \\
\text { on* }\end{array}$ & $\begin{array}{l}\text { Number of } \\
\text { respondents }\end{array}$ \\
\hline Italy: Sicilia, Sardegna & 2.5 & 0.36 & 99 & 529 \\
\hline $\begin{array}{l}\text { Germany: Bayern } \\
\text { Spain: Centro, Canaries }\end{array}$ & 2.1 & 0.33 & 83 & 443 \\
\hline $\begin{array}{l}\text { Italy: All other regions } \\
\text { Spain: Madrid, Sur }\end{array}$ & 2.0 & 0.46 & 90 & 1512 \\
\hline $\begin{array}{l}\text { France: Est } \\
\text { Germany: Baden-Württemberg } \\
\text { Spain: Noroeste }\end{array}$ & 1.8 & 0.44 & 72 & 1021 \\
\hline $\begin{array}{l}\text { Belgium: Brussels } \\
\text { France: Calais } \\
\text { Netherlands: Nord }\end{array}$ & 1.7 & 0.38 & 53 & 439 \\
\hline $\begin{array}{l}\text { Belgium: Vlaams, Wallone } \\
\text { France: Méditerranée } \\
\text { Germany: Hessen, Nordrhein-West- } \\
\text { falen, Rheinland-Pfalz } \\
\text { Netherlands: Oost, Zuid }\end{array}$ & 1.5 & 0.32 & 75 & 2675 \\
\hline $\begin{array}{l}\text { France: Île-de-France, Bassin parisi- } \\
\text { en, Ouest, Sud Ouest, Centre-Est } \\
\text { Germany: Niedersachsen, Schles- } \\
\text { wig-Holstein } \\
\text { Netherlands: West }\end{array}$ & 1.3 & 0.40 & 60 & 2013 \\
\hline $\begin{array}{l}\text { Denmark: all regions except Copen- } \\
\text { hagen }\end{array}$ & 1.1 & 0.30 & 0 & 1122 \\
\hline $\begin{array}{l}\text { Denmark: Copenhagen } \\
\text { Germany: Thüringen } \\
\text { Sweden: all regions except Stock- } \\
\text { holm }\end{array}$ & 0.8 & 0.42 & 2 & 1295 \\
\hline $\begin{array}{l}\text { Germany: Mecklenburg-Vorpom- } \\
\text { mern, Sachsen } \\
\text { Sweden: Stockholm }\end{array}$ & 0.6 & 0.35 & 9 & 648 \\
\hline $\begin{array}{l}\text { Germany: Berlin, Brandenburg, } \\
\text { Sachsen-Anhalt }\end{array}$ & 0.4 & 0.28 & 19 & 475 \\
\hline
\end{tabular}

* computed among people who say that they belong to a denomination. 
The table shows that two Italian regions, Calabria and Sicily, have the highest score on Christian beliefs. These two regions do not differ in relation to denomination, and both are a part of the same country. As shown in row three, the other Italian regions show less support for Christian beliefs. If a «state matters» explanation is correct, all Italian regions should have been collapsed into the same category. This is not the case. This means that some explanation other than country-based variables (such as GDP, state regulation or, for that matter, some measure of a special Italian culture) must be at stake. In other words, a comparison of the first and the third rows indicates that an analysis limited to a comparison of countries overlooks important differences within countries. Moving through the table, it can be seen that there are no instances in which all regions in a country are located in the same category. Hence, the result for Italy may be generalized to all the countries: An analysis of Christian beliefs is limited or even misleading when researchers only compare countries.

This said, there is a tendency for regions in different countries to be more similar than different- except for Germany, which will be discussed shortly. The regions for each country are not scattered randomly in the table but tend to cluster, i.e. to be located in rows that follow each other. This indicates that there are important differences in countries but also that the regions in each country tend to «familiarize».

One might think that neighboring regions would be identical with respect to secularization, but this is far from always the case. For instance, the eastern and not the southern regions of France have been collapsed into the same category as have regions in the northern parts of Spain. There are, however, cases in which neighboring crossnational regions are classified in the same category. Copenhagen, for instance, is categorized in the same category as Skåne, its neighboring region in Sweden, but the analysis shows that all Swedish regions except for Stockholm belong to the same category, i.e. that the distribution of Christian beliefs in Copenhagen is not only identical to regions in southern Sweden but also to regions in the northern parts of Sweden. These examples show that there are important in-country differences in Christian beliefs, and there is no clear tendency for regions on both sides of a national border to be identical. In other words, country characteristics play a role for secularization, but variations in secularization cannot be reduced to country differences.

Germany, as mentioned, represents the most complicated picture. The German regions are scattered all over the table with Bavaria in row two as a region with strong support for Christian values, whereas Berlin, Brandenburg and Sachsen-Anhalt are located at the bottom of the table and characterized by the least support for Christian values as well as the lowest correlation between morality and Christian beliefs. The explanation for this difference among the German regions is regional differences in denomination and the differing histories of East and West Germany. If the table is read vertically, the former West German regions are at the top of the table, and the Catholic regions are located higher than the Protestant regions. The former East German regions are located at the bottom, which is no doubt a consequence of the attempts to diminish the role of religion in the DDR. From a cohort perspective, these regions include people whose religious socialization have been very restricted, which, in turn, leads to less support for Christian values and a smaller impact of Christian values on morality. 
So far, the analysis has shown that a country-based explanation is inadequate: there are important differences between regions in each country. The next step is to discuss whether there are institutional border-crossing explanations for the level of Christian beliefs. This may be illustrated with the data in column four in Table 2 . The column distinguishes between two types of religious institutions: countries dominated by Protestant and by Catholic denominations. This is not just a distinction between two faiths but includes a broader range of cultural and political characteristics (Davie 2000). For each category of collapsed regions is presented the percentage of respondents who say that they belong to the Catholic Church. Comparing the upper and the lower part of the table according to denomination in each region, it becomes clear that the regions in the lower part of the table belong to Protestant denominations, whereas the upper part of the table consists of regions that belong to the Catholic faith. This shows the importance of religious institutions (where the region is dominated by Protestant or Catholic denominations) for secularization. However, this analysis should only be considered as a rough estimate of the denomination as a societal institution.

In the EVS study, people were asked about their denomination in two steps: first, they were asked whether they belonged to a denomination and, second, they were asked which denomination they belonged to. Of the 16,542 respondents, 12,066 (72 pct.) said that they belonged to a denomination. This makes the analysis complicated because of national differences in the frequency of people who belong to a denomination. In some countries such as Protestant Denmark or Catholic Italy, almost everybody belongs to a denomination, whereas only about half of the respondents in regions in France, The Netherlands or Belgium, for instance, belong to a denomination. If a better measure were available of religious institutions at the regional level than aggregated survey data, it would be possible to do a more refined analysis, but the data in Table 2 still suggests that it is plausible that the character of the religious institution plays a vital role in explaining the level of Christian beliefs.

Returning to the hypothesis 2 about the relationship between a country-based and a region-based analysis, the analysis has shown that both explanations may be relevant. There are important differences in each country with respect to religious values, which means that a country-based analysis may be problematic, but regions within countries also tend to cluster, which provides some support to a country-based approach. The interpretation of the country variable needs to be elaborated more than is possible in this article. Country differences may be due to factors that are traditionally used in modernization theory (e.g. wealth), but an institutionalist approach to understanding country differences would include the role of the state church (Davie 2002) or state regulations of religion. The predominant denomination is a separate institution that may cross state boundaries. This institution has an impact on how people think about religion and about their religious behavior.

\section{Cohort, Region and Religious Socialization}

The preceding sections have analyzed the importance of regions and religious socialization for secularization, and this section combines the results of these analyses. As 
mentioned, the analysis of regions and socialization could only be carried out on the 2008 data. Secularization is a process and should be studied from a time perspective as was done in the first part of this article. In order to study change, cohorts have been included in the analysis. By comparing the analysis of the impact of socialization and regions on Christian beliefs - and on the relationship between Christian beliefs and morality - we should be able to analyze social change by comparing older and younger cohorts. The expectation is that secularization is stronger in younger than in older generations and that this is the case even when regions and socialization are included in the analysis.

Table 3 shows the two measures of secularization: Christian beliefs and the relationship between Christian beliefs and morality for a combination of cohorts, region, and religious socialization. In order to simplify the analysis, the three variables have been recoded as follows: Cohort: 1) born 1945 or before, 2) born 1946 or later, regions recoded in 1) traditionally Catholic and 2) traditionally Protestant regions, Religious socialization, church attendance at age 12 1) once a year or more often, 2) less often or never.

The table consists of two parts - one for each measure of secularization, the mean value of Christian beliefs and the $\gamma$ value of the correlation between Christian beliefs and morality.

Table 3. The relationship between cohort, regions, socialization and secularization-measured by means with respect to Christian beliefs and $\gamma$-values for the relationship between Christian beliefs and morality.

\begin{tabular}{|l|l|c|c|}
\hline \multicolumn{4}{|c|}{ Means, Christian beliefs } \\
\hline Cohorts & \multicolumn{1}{|c|}{ Socialization } & $\begin{array}{c}\text { Protestant-dominated } \\
\text { regions }\end{array}$ & $\begin{array}{c}\text { Catholic-dominated } \\
\text { regions }\end{array}$ \\
\hline Born-1945 & Strong socialization & 1.4 & 1.6 \\
\hline Born -1945 & Weak socialization & 0.8 & 0.7 \\
\hline Born 1946- & Strong socialization & 1.2 & 1.4 \\
\hline Born 1946- & Weak socialization & 0.6 & 0.4 \\
\hline & $\gamma$-correlations between Christian beliefs and morality \\
\hline Cohorts & Socialization & $\begin{array}{c}\text { Protestant-dominated } \\
\text { regions }\end{array}$ & $\begin{array}{c}\text { Catholic-dominated } \\
\text { regions }\end{array}$ \\
\hline Born-1945 & Strong socialization & 0.30 & 0.41 \\
\hline Born -1945 & Weak socialization & $(0.18)$ & 0.30 \\
\hline Born 1946- & Strong socialization & 0.38 & 0.44 \\
\hline Born 1946- & Weak socialization & $(-0.03)^{*}$ & $(0.28)^{*}$ \\
\hline
\end{tabular}

* $\gamma$-values in parentheses mean that the correlation is insignificant $(p>0.01)$. 
Comparing, first, the difference between strong and weak socialization, we find that people who are strongly socialized into religion tend to be less secular. This result holds even when in a comparison of cohorts and denominations and supports the argument about the importance of socialization for secularization.

We should also expect that people in Catholic regions have stronger Christian beliefs than people in Protestant regions. This expectation is confirmed among those who have been strongly socialized in religion. However, when we compare people who are weakly socialized, we find the opposite result: people who live in Protestant regions tend to have higher levels of Christian beliefs compared to people who live in Catholic regions. This surprising result may be due to differences in religious cultures in Protestant and Catholic regions. In Protestant regions, it is more common for people not to go to church. Perhaps, people who do not go to church in a Catholic region may be considered as unusual. Hence, not going to church as a child is related to a stronger anti-religious conviction in Catholic rather than in Protestant regions. In other words, there may be a selection process rather than a socialization process taking place.

\section{Conclusion and Discussion}

Based on a most-similar-approach designed analysis of Western European countries, this article has gone into detail with two contested factors in determining secularization at the individual level: cohort and country. The most important aspect of using cohorts is the degree to which people are socialized into religion. As people are less socialized, they tend to be less religious. Hence, religious socialization functions almost like a machine: a decline in religious socialization results in less religiosity, which, in turn, leads to less socialization. If socialization, the cause of decline in religiosity, does not change, the process of secularization seems to be irreversible (see Lieberson 1985). Are there factors that may change this development? An answer to this question may depend on which socialization agents and processes are considered. Due to limitations in data, it has only been possible to use church attendance at the age of 12 as an operationalization of religious socialization. This operationalization does not answer the question of the impact of socialization agents; it only shows that people who attended the church to a lesser degree as children tend to have fewer Christian beliefs and more value fragmentation between religious and secular values. Parents, peers, the church, the school and the media are important socialization agents. An increased emphasis on religion among these agents may increase socialization and may reverse the tendency toward increased secularization in the long run.

An example of such change might be an increased emphasis on teaching Christian values in schools. However, such a development does not seem very likely (Davie 2000). Another type of impact is through confirmation classes. Niemelä (2006) has shown that, in Finland, young people's attitudes toward Christianity and belief in God frequently became more positive during confirmation classes. It is difficult to tell whether such result may be generalized and whether the short-term effect of confirmation classes also results in long-term effects. At any rate, the consequences of this 
change depend on the frequency young people attend confirmation classes. For instance, in Denmark, there was an increase in confirmation frequency for 14-year-old persons of Danish origin from 0.78 to 0.79 from 2008 to 2013 (Statistikbanken 2014). This small change will hardly alter the process of secularization, and the general decrease in many other Western European countries of people leaving majority churches does not make it likely that new modes of socialization will result in less secularization.

Socialization as a mechanism for social change, of course, raises the question of how or why the decrease in religiosity occurred in the first place. The socialization machine must start sometime. It seems likely that the causal processes behind secularization may vary in different periods of time and that we should be careful not to generalize the explanations for the period after 1970 to earlier periods. The steep increase in secularization indicates that secularization before WWII may be related to period effects such as, for instance, urbanization or educational changes.

The other part of the article suggested that country comparisons may conceal the fact that there are important differences in secularization within countries. The choice of country as a unit for analysis is often convenient because macro-data are available at the country level, but it may be just as important to investigate the differences in secularization within countries or in border-crossing regions between countries.

Including sub-country regions in the analysis expands the analysis of secularization, and this article has suggested that secularization may be explained not only by country-related factors but also by institutions that characterize regions in different countries. The importance of the religious institution is, perhaps, most clearly seen in the analysis of a single country - Germany - where both the regional differences in traditional denominations and the different histories of East and West Germany play an important role in understanding the process of secularization.

In short, this article has contributed two results. First, there is a strong and stable result that social change due to cohort replacement may be primarily understood by the respondents' religious socialization during their formative years. Second, there is the result that not only country but institutional explanations are important for understanding secularization and that this may be studied by comparing border-crossing regional variations. This article has focused on the impact of religious institutions; but, when it comes to the impact of other border-crossing institutions, more work is needed to identify and classify the most relevant institutions. The fact that several interacting institutions may have an impact on secularization does not make this task any easier.

\section{Notes}

1 For general information about the EVS project, see http://www.europeanvaluesstudy.eu/ and http://www.atlasofeuropeanvalues.eu/new/.

$2 \gamma$ is a rank correlation coefficient, which is suited for ordinal data. Partial $\gamma$ coefficients are measures of correlations when controlling for the other variables in the model - akin to $\beta \mathrm{s}$ in OLS multiple regressions.

3 For tecinical reasons Great Britain was omitted for this part of the analysis. 


\section{References}

Andersen, Peter B. and Peter Lüchau 2011. Individualisering og aftraditionalisering af danskernes religiøse værdier [Individualization and de-Traditionalization of the Danes' Religious Values]. In Små og store forandringer. Danskernes verdier siden 1981 [Large and Small Changes. The Danish Values after 1981], Peter Gundelach (ed.), 76-96. Copenhagen: Hans Reitzels forlag.

Andersen, Peter B., Peter Gundelach and Peter Lüchau, 2013. A Spiritual Revolution in Denmark? Journal of Contemporary Religion 28 (3): 385-400.

Aneshensel, Carol S. 2002. Theory-Based Data Analysis for the Social Sciences. Thousand Oaks: Pine Forge Press.

Arts, Will and Loek Halman 2014. Cross-National Values in Europe Today: Facts and Explanations. In Value Contrasts and Consensus in Present-Day Europe. Painting Europe's Moral Landscapes, Will Arts and Loek Halman (eds.), 1-17. Leiden: Brill.

Beck, Ulrich 2002. The Cosmopolitan Society and Its Enemies. Theory, Culture and Society 19 (1-2): 17-44.

Beck, Ulrich and Elisabeth Beck-Gernsheim 2009. Global Generations and the Trap of Methodological Nationalism. For a Cosmopolitarian Turn in the Sociology of Youth and Generation. European Sociological Review 25(1): 25-36.

Bruce, Steven 2011. Secularization. Oxford: Oxford University Press.

Cornwall, Marie 1988. The Influence of Three Agents of Religious Socialization: Family, Church, and Peers. The Religion and Family Connection: Social Science Perspectives 16 (2): 207-231.

Davie, Grace 2000. Religion in Modern Europe: A Memory Mutates. Oxford: Oxford University Press.

Davie, Grace 2002. Europe: The Exceptional Case. London: Darton.

Davis, James A. 1971. Elementary Survey Analysis. Englewood Cliffs: Prentice-Hall.

Desmond, Scott A. and Rachel Kraus 2014. The Effects of Importance of Religion and Church Attendance on Adolescents' Moral Beliefs. Sociological Focus 47(1), 11-31.

Dobbelaere, Karel 2002. Secularization: An Analysis at Three Levels. Brussels: Peter Lang.

Finke, Roger and Amy Adamczyk 2008. Cross-National Moral Beliefs: The Influence of National Religious Context. The Sociological Quarterly 49(4): 617-652.

Gundelach, Peter 1994. National Value Differences: Modernization or Institutionalization? International Journal of Comparative Sociology XXXV(1-2): 37-58.

Haller, Max 2002. Theory and Method in the Comparative Study of Values: Critique and Alternative to Inglehart. European Sociological Review 18(2): 139-158.

Halman, Loek and Veerle Draulans 2006. How Secular is Europe? The British Journal of Sociology, 57(2): 263-288.

Halman, Loek and Erik van Ingen 2013. Secularization and the Sources of Morality in Contemporary Europe. In Religion and Civil Society in Europe, Jan de Hart, Paul Dekker and Loek Halman (eds.), 87-108. Dordrech: Springer.

Himmelfarb, Harold S. 1980. The Study of American Jewish Identification: How It Is Defined, Measured, Obtained, Sustained and Lost. Journal for the Scientific Study of Religion 19(1): 48-60.

Immerzeel, Tim and Frank Van Tubergen 2013. Religion as Reassurance? Testing the Insecurity Theory in 26 European Countries. European Sociological Review 29(2): 359-372.

Inglehart, Ronald 1997. Modernization and Postmodernization: Cultural, Economic, and Political Change in 43 Societies. Princeton, NJ: Princeton University Press. 
Inglehart, Ronald and Christian Welzel 2005. Modernization, Cultural Change, and Democracy: The Human Development Sequence. Cambridge: Cambridge University Press.

Joas, Hans and Klaus Wiegandt (eds.) 2009. Secularization and the World Religions. Liverpool: Liverpool University Press.

Kreiner, Svend 1996. An Informal Introduction to Graphical Modelling. In Mental Health Service Evaluation, Helle Charlotte Knudsen and Graham Thornicroft (eds.), 156-175. Cambridge: Cambridge University Press.

Kreiner, Svend 2013. User Guide to DIGRAM. A Program for Discrete Graphical Modeling. Available from: http://staff.pubhealth.ku.dk/ skm/skm/ [Accessed 2 July 2014].

Lauritzen, Steffen L. 1996. Graphical Models. Oxford: Oxford University Press.

Lazarsfeld, Paul F. and Morris Rosenberg (eds.) 1955. The Language of Social Research. New York: The Free Press.

Lieberson, Stanley 1985. Making It Count. The Improvement of Social Research and Theory. Berkeley: University of California Press.

Lüchau, Peter 2014a. A New Approach to Secularization on the Individual Level. The Declining Social Significance of Religion in Denmark. Journal of Religion in Europe 7(2): 93-115.

Lüchau, Peter 2014b. Church-Attendance in Denmark since 1950 (personal communication).

Martin, David 1978. General Theory of Secularization. Oxford: Basil Blackwell.

Meulemann, Heiner 1983. Value Change in West Germany, 1950-1980: Integrating the Empirical Evidence. Social Science Information/sur les sciences sociales 22(4-5): 777-800.

Moor, Nienke 2014. Religious Vitality and Church Attendance in Europe. In Value Contrasts and Consensus in Present-Day Europe. Painting Europe's Moral Landscapes, Will Arts and Loek Halman (eds.), 213-230. Leiden: Brill.

Niemelä, Kati 2006. The Quality and Effectiveness of Confirmation Classes in Finland. Journal of Beliefs \& Values 27(2): 177-190.

Norris, Pippa and Ronald Inglehart 2004. Sacred and Secular: Religion and Politics Worldwide. Cambridge: Cambridge University Press.

Parboteeah, K. Praveen, Martin Hoegl and John B. Cullen 2008. Ethics and Religion: An Empirical Test of a Multidimensional Model. Journal of Business Ethics 80(2): 387-398.

Putnam, Robert D. and David E. Campbell 2012. American Grace: How Religion Divides and Unites Us. New York: Simon and Schuster.

Ruiter, Stijn and Frank van Tubergen 2009. Religious Attendance in Cross-National Perspective: A Multilevel Analysis of 60 Countries. American Journal of Sociology 115(3): 863895.

Ryder, Norman B. 1965. The Cohort As a Concept in the Study of Social Change. American Sociological Review 30(6): 843-861.

Stark, Rodney 2001. Gods, Rituals and the Moral Order. Journal for the Scientific Study of Religion 40(4): 619-636.

Statistikbanken 2014. Antal konfirmerede og befolkningens fordeling i Danmark 2008-2013 [Confirmation and Population Distribution in Denmark 2008-2013] [online]. Available from www.statistikbanken.dk [Accessed 2 August 2014].

Stubager, Rune 2008. Education Effects on Authoritarian-Libertarian Values: A Question of Socialization. British Journal of Sociology 59(2): 327-350.

Todd, Emmanuel 1985. The Explanation of Ideology: Family Structures and Social Systems. London: Basil Blackwell.

Tomka, Miklós 1995. The Changing Social Role of Religion in Eastern and Central Europe: Religion's Revival and Its Contradictions. Social Compass 42(1): 17-26. 
Voas, David and Alistair Crockett 2005. Religion in Britain: Neither Believing nor Belonging. Sociology 39(1): 11-28.

Voas, David and Stephanie Doebler 2014. Secularization in Europe: An Analysis of Inter-Generational Religious Change. In Value Contrasts and Consensus in Present-Day Europe. Painting Europe's Moral Landscapes, Will Arts and Loek Halman (eds.), 231-248. Leiden: Brill. Wilson, Bryan 1982. Religion in Sociological Perspective. Oxford: Oxford University Press. 
Copyright of Nordic Journal of Religion \& Society is the property of Akademika Publishing and its content may not be copied or emailed to multiple sites or posted to a listserv without the copyright holder's express written permission. However, users may print, download, or email articles for individual use. 